\title{
MINAT SISWA SMP NEGERI MELANJUTKAN KE SMK DITINJAU DARI SOSIAL EKONOMI KELUARGA DI KABUPATEN BANTUL
}

\author{
Rony Windarto \\ Program Studi Pendidikan Teknologi dan Kejuruan PPs UNY \\ ronilucky@gmail.com
}

\begin{abstract}
Abstrak
Penelitian ini adalah untuk mengetahui pengaruh minat siswa SMP Negeri dalam melanjutkan sekolah di SMK ditinjau dari sosial ekonomi keluarga di Kabupaten Bantul. Desain penelitian ini adalah ex post facto. Populasi penelitian ini adalah siswa kelas IX SMP Negeri tahun ajaran 2012/2013 di Kabupaten Bantul. Dari populasi di atas diambil 17 SMP sebagai sampel penelitian, sehingga sampel penelitian menjadi 364 orang, yang diambil secara proporsional random sampling. Instrumen untuk pengambilan data menggunakan angket. Teknik analisis data yang digunakan yaitu uji person correlation dan regresi ganda. Hasil penelitian menunjukkan bahwa pengaruh antara lingkungan siswa dengan minat sebesar 0,627, kesejahteraan keluarga dengan minat siswa sebesar -0,227, informasi pendidikan dengan minat siswa sebesar -0,181, pemenuhan kebutuhan keluarga dengan minat siswa sebesar -0,156, dan nilai $F$ sebesar 65,037 dengan nilai sig 0,000 dengan persamaan regresi $Y=44,623+0,533 X 1-0,113 X 2-0,122 X 3-0,089 X 4$, Sumbangan variabel bebas mempunyai pengaruh $42 \%$ terhadap minat siswa SMP Negeri dalam melanjutkan sekolah di SMK.
\end{abstract}

Kata kunci : sosial ekonomi keluarga, minat siswa

\section{CONTINUING PUBLIC INTEREST TO STUDENTS VOCATIONAL VIEWED FROM THE SOCIO ECONOMIC FAMILY IN THE DISTRICT BANTUL}

\author{
Rony Windarto \\ Program Studi Pendidikan Teknologi dan Kejuruan PPs UNY \\ ronilucky@gmail.com
}

\begin{abstract}
The aim of this study is to find out the effects between public junior high school students' interests in continuing their studies in vocational high schools and their families' socio-economic in Bantul Regency.This study employed the ex post facto design. The research population comprised 7718 Grade IX students of 48 public junior high schools in the academic year of 2012/2013 in Bantul Regency. From the population, 17 junior high schools were selected as the sample, consisting of 364 students, selected by means of the proportional random sampling technique. The data were collected through a questionnaire. The data analysis techniques, namely the Pearson's product moment correlation and multiple regression. The results of the study show that the correlation coefficient between the students environments and their interests is 0.627 , the family welfare and their interests is -0.227, the educational information and their interests is -0.181 , and the family need fulfilment and their interests is -0.156, and an $F$ value of 65.037 at a significance value of 0.000 with the regression equation $Y=44.623+0.533 X 1-0.113 X 2-0.122 X 3-0.089 X 4$. The independent variables have a contribution of $42 \%$ to public junior high school students' interests in continuing their studies in vocational high.
\end{abstract}

Keywords: families socio-economic backgrounds, students interests 


\section{PENDAHULUAN}

Pendidikan merupakan sebuah kebutuhan yang sangat penting bagi kehidupan masyarakat, meskipun kebutuhan akan pendidikan setiap orang tidak sama, baik jenjang maupun jenisnya. Mulai dari kandungan sampai beranjak dewasa kemudian tua manusia mengalami proses pendidikan yang didapatkan dari orang tua, masyarakat, maupun lingkungannya. Pendidikan bagaikan cahaya penerang yang berusaha menuntun manusia dalam menentukan arah, tujuan dan makna kehidupan ini. Manusia sangat membutuhkan pendidikan melalui proses penyadaran yang berusaha menggali dan mengembangkan potensi dirinya lewat metode pengajaran atau dengan cara lain yang telah diakui oleh masyarakat. Banyak faktor yang dapat menyebabkan hal tersebut terjadi dan salah satu di antaranya adalah faktor status sosial ekonomi. Semakin tinggi status sosial ekonomi seseorang maka semakin selektif dalam memilih jenis pendidikan. Jadi faktor sosial ekonomi turut menentukan jenis pendidikan yang ditempuh oleh seseorang.

Jenjang pendidikan pada pendidikan formal terdiri dari: (1) pendidikan dasar (SD dan SMP), (2) pendidikan menengah (SMA dan SMK), dan (3) pendidikan tinggi (Diploma dan Sarjana). Untuk siswa kelas IX SMP (Sekolah Menengah Pertama) mereka harus memikirkan apakah mereka akan melanjutkan ke SMA atau melanjutkan ke SMK. Berdasarkan PP No 17 tahun 2010 pasal 76, fungsi dari pendidikan menengah umum (SMA) adalah meningkatkan kesiapan fisik dan mental untuk melanjutkan pendidikan ke jenjang pendidikan tinggi dan atau untuk hidup mandiri di masyarakat, sedangkan pendidikan menengah kejuruan (SMK) berfungsi membekali peserta didik dengan kemampuan ilmu pengetahuan dan teknologi serta kecakapan kejuruan para profesi sesuai dengan kebutuhan masyarakat.

Pendidikan menengah kejuruan merupakan pendidikan pada jenjang pendidikan menengah yang mengutamakan pengembangan kemampuan peserta didik untuk dapat bekerja dalam bidang tertentu, kemampuan beradaptasi di lingkungan kerja, melihat peluang kerja, dan mengembangkan keterampilan diri untuk dapat hidup secara mandiri di kemudian hari. Mengingat begitu banyaknya satuan pendidikan yang ada baik itu satuan pendidikan menengah atas, menengah kejuruan, menengah keagamaan maupun pendidikan menengah lainnya, maka para lulusan SMP dituntut untuk dapat memilih jenis pendidikan menengah yang sesuai dengan minatnya, bakat, dan kemampuannya. Tentunya faktor-faktor tersebut saling berkaitan antara ketiganya dalam artian siswa memilih jenis pendidikan yang dipilihnya harus berdasarkan minat dengan didukung oleh bakat serta kemampuan sosial ekonomi orang tuanya.

Pemilihan melanjutkan sekolah tentu bukanlah persoalan mudah karena banyak faktor yang mempengaruhi. Faktor tersebut dapat dipengaruhi dari orang tua, rekan siswa, teman sepergaulan, atau faktor minat, jurusan tertentu di SMK. Setiap siswa yang akan menyelesaikan studinya di Sekolah Menengah Pertama (SMP) akan berhadapan pada berbagai pilihan, apakah akan melanjutkan pendidikannya ke SMA, SMK, atau mengikuti kursus, mencari pekerjaan atau menganggur. Terutama bagi siswa kelas IX mereka harus lebih dulu memikirkan arah kedepannya sehingga dapat menekuni apa yang seharusnya siswa kerjakan setelah tamat dan tentu harus memikirkan sekolah mana yang cocok sebelum melanjutkan pada jenjang pendidikan yang tinggi yaitu masuk ke SMA atau masuk ke SMK. Bagi siswa SMP yang akan memantapkan pilihan untuk melanjutkan ke SMK, tentu akan dihadapkan lagi pada jurusan atau program studi yang akan dipilih, setelah Ujian Akhir Nasional dilaksanakan.

Mungkin ada siswa yang memang memiliki minat yang tinggi, adapula siswa yang tidak memiliki minat untuk melanjutkan studi di SMK, sehingga hanya sampai pada tingkat SMP. Sedangkan bagi siswa yang ingin mengembangkan minat yang dimiliki tentu cenderung akan memilih jurusan atau program studi yang sesuai dengan arah pilihan karirnya. Pemilihan melanjutkan pendidikan ke SMK tidaklah mudah. Sehingga untuk dapat melanjutkan pendidikan tentu harus mempertimbangkan aspek kemampuan masing-masing siswa, sehingga siswa dapat diharapkan mengetahui pula faktor-faktor sosialisasi tentang sekolah yang akan dipilih tersebut. Siswa nantinya betul-betul dapat mengetahui dan memahami visi dan misi sekolah yang berkaitan dengan masa depan seseorang setelah tamat nanti. Berdasarkan 
data terakhir Sistem Informasi Biro Perencanaan dan Departemen Pendidikan Nasional tahun 2007 di Kabupaten Bantul jumlah SMP/MTs sebanyak 117 buah dengan rincian Sekolah Negeri sebanyak 79 buah, Swasta sebanyak 38 buah. Sedangkan SMA/ MA sebanyak 45 buah dengan rincian 28 buah Sekolah Negeri dan 17 buah Sekolah Swasta. Untuk SMK sebanyak 35 dengan rincian Sekolah Negeri sebanyak 13 buah dan Swasta sebanyak 22 buah.

Data Departemen Pendidikan Nasional Direktorat Jendral Manajemen Pendidikan Dasar dan Menengah Data Pokok PSMK 2008 di Kabupaten Bantul tercatat sejumlah 30 Sekolah Menengah Kejuruan. Sedangkan jumlah lulusan SMP tahun 2008 sebanyak 10.097 siswa dari 106 SMP yang ada di Bantul. Siswa yang mendaftar di SMK sebanyak 4.753 dan yang diterima sejumlah 3.963 atau sekitar $83,38 \%$ dari keseluruhan pendaftar yang diterima dan hanya 39,25\% dari jumlah lulusan SMP tahun 2008. Sedangkan menurut data (Penerimaan Peserta Didik Baru (PPDB) 2009 dari sejumlah 13 SMK Negeri di Kabupaten Bantul yang memiliki daya tamping keseluruhan sebanyak 2.868 menyebutkan bahwa jumlah formulir PPDB yang masuk ke SMK Negeri di Kabupaten Bantul sebanyak 3211 formulir. Dari hasil tersebut sebanyak 343 siswa yang tidak diterima di SMK Negeri dimungkinkan mendaftar ke SMK Swasta maupun ke SMA.

Sumber lain yang terlampir pada Surat Keputusan Penetapan Daya Tampung SMA dan SMK di lingkungan Dinas Pendidikan Menengah dan Nonformal Tahun Pelajaran 2009/2010 Nomor 042 Tahun 2009 Tanggal 22 Juni 2009 di Kabupaten Bantul menerangkan bahwa jumlah siswa dari 36 SMK yang terdaftar adalah sebanyak 5.692 siswa dengan rombongan belajar sebanyak 163 kelompok. Sedangkan menurut data yang sama dari 33 SMA yang tercatat daya tampungnya sebanyak 4.020 siswa dengan jumlah rombongan belajar sebanyak 122 kelompok. Jika data tersebut dipersentase maka didapatkan perbandingan antara siswa yang masuk di SMK dengan siswa yang masuk di SMA di Kabupaten Bantul yaitu 58,61\%:41,39\%, lebih banyak siswa yang masuk ke SMK. Sedangkan fenomena yang terjadi, pada setiap tahun ajaran baru sering timbul keresahan orang tua kalau anaknya tidak dapat menerus- kan sekolahnya atau putus sekolah karena biaya pendidikan yang begitu mahal.

Walaupun pemerintah sudah ikut berperan serta dalam penyelenggaraan pendidikan seperti adanya anggaran khusus untuk pendidikan atau subsidi, tetapi biaya untuk pendidikan tidaklah hanya dari pemerintah saja tapi biaya pendidikan yang paling banyak adalah dari orang tua. Biaya pendidikan yang dikeluarkan oleh pemerintah digunakan untuk membiayai fasilitas yaitu antara lain menyediakan atau mendirikan gedung sekolah sebagai sarana dan prasarana yang memadai, sedangkan biaya pendidikan seperti biaya untuk membayar BP3, SPP dan biaya-biaya untuk kelengkapan sarana dan prasarana yang menunjang adalah dikeluarkan oleh orang tua. Sehingga orang tua atau keluarga dari anak yang bersangkutan harus mengeluarkan biaya khusus demi pendidikan anaknya. Orang tua yang mempunyai penghasilan tinggi, dalam pemenuhan kebutuhan sekolah anak tidak akan mengalami kesulitan, berbeda dengan orang tua yang mempunyai penghasilan rendah. Orang tua memegang peranan penting bagi pendidikan anaknya yaitu disamping sebagai pendidik yang utama juga sebagai penyandang dana dalam pemenuhan kebutuhan pendidikan anaknya tersebut.

Masalah kondisi sosial dan kondisi ekonomi orang tua tentang harapan masa depan anak dari orang tua pada akhirnya akan menimbulkan masalah bagi orang tua untuk menentukan alternatif pilihan terhadap kelanjutan sekolah bagi anak-anaknya. Minat anak untuk melanjutkan pendidikan ke jenjang yang lebih tinggi dipengaruhi oleh beberapa faktor, seperti: cita-cita atau aspirasi, kemampuan belajar, kondisi siswa (kondisi fisik dan kondisi psikologis), kondisi lingkungan (lingkungan keluarga, lingkungan sekolah serta lingkungan masyarakat).

Keadaan sosial ekonomi keluarga tentulah berpengaruh terhadap perkembangan anak-anak, apabila kita perhatikan bahwa dengan adanya perekonomian yang cukup, lingkungan material yang dihadapi anak di dalam keluarganya itu lebih luas, ia mendapat kesempatan yang lebih luas untuk mengembangkan bermacam-macam kecakapan yang tidak dapat ia kembangkan apabila tidak ada prasarananya. (Gerungan, 2010:196).

Keragaman latar belakang ekonomi orang tua tersebut dapat berpengaruh pula 
pada kemampuan membiayai kepada anakanaknya, sehingga keadaan sosial ekonomi orang tua merupakan salah satu faktor yang menentukan keberhasilan pendidikan anak. Keluarga bertanggung jawab menyediakan dana untuk kebutuhan pendidikan anak. Keluarga (orang tua) yang keadaan sosial ekonominya tinggi tidak akan banyak mengalami kesulitan dalam memenuhi kebutuhan sekolah anak, berbeda dengan orang tua yang keadaan sosial ekonominya rendah. Contohnya: anak dalam belajar akan sangat memerlukan sarana penunjang belajarnya, yang kadang-kadang harganya mahal. Bila kebutuhannya tidak terpenuhi maka ini akan menjadi penghambat bagi anak dalam pembelajaran.

Orang tua siswa yang kalah seleksi secara finansial atau keuangan, mereka diultimatum, direkomendasikan atau sangat dianjurkan agar memilih SMK saja. Maka jadilah SMK ini sebagai tempat bersekolahnya anak-anak dengan mental inferior complex, berasal dari orang tua dengan ekonomi lemah dan anak-anak yang kualitas otaknya kurang beruntung. Dari latar belakang masalah yang ada maka salah satu faktor yang akan diteliti dalam penelitian ini adalah minat siswa melanjutkan ke Sekolah Menengah Kejuruan dilihat dari faktor kondisi sosial ekonomi orang tua.

Minat adalah kecenderungan yang besar terhadap sesuatu, dalam kamus besar Bahasa Indonesia minat diartikan sebagai kecenderungan hati yang tinggi terhadap sesuatu, gairah, keinginan (Depdikbud,1991:656). Beberapa ahli psikologi memberikan pendapat mengenai definisi minat yang pada dasarnya mempunyai makna yang sama, namun memberikan penekanan yang berbeda. Menurut W.S. Wingkel (1995:31) minat merupakan kecenderungan yang agak menetap dalam diri subjek, sehingga ia merasa tertarik pada suatu bidang atau hal-hal tertentu, dan merasa senang berkecimpung di dalam bidang atau hal tersebut. Dalam kaitanya dengan penelitian ini maka objek yang dimaksud adalah minat siswa SMP Negeri untuk melanjutkan ke Sekolah Menengah Kejuruan (SMK) ditinjau dari kondisi sosial ekonomi keluarga. Perbedaan minat dapat disebabkan oleh tingkat sosial ekonomi, pendapatan dan tingkat pendidikan.
Faktor dari dalam diri siswa adalah faktor yang menentukan ke mana arah dan tujuan setelah menamatkan diri dari jenjang pendidikan. Di mana yang paling menonjol di sini adalah berupa faktor kemauan yang timbul dari dalam diri seseorang misalnya menurut Dalyono (2010:56) yaitu "bakat, sikap, dan intelegensi". Minat yang dimiliki tersebut akan dikembangkan untuk dapat melanjutkan ke sekolah yang lebih tinggi. Sedangkan faktor-faktor eksternal adalah faktor individu yang turut mempengaruhi minat seseorang terhadap suatu objek atau benda, menurut Dalyono (2010:59) faktor luar ini juga biasa dipengaruhi oleh lingkungan keluarga, sekolah, dan masyarakat.

Siswa SMP kelas 3 dihadapkan pada pemilihan jenjang pendidikan yang akan dipilihnya. Diantaranya: Sekolah Menengah Atas (SMA), Madrasah Aliyah (MA), Sekolah Menengah Kejuruan (SMK), dan Madrasah Aliyah Kejuruan (MAK), atau bentuk lain yang sederajat. Pemilihan untuk melanjutkan ke jenjang yang lebih tinggi haruslah didasari dengan adanya minat. Karena apabila suatu kegiatan didasari dengan adanya minat maka ia akan termotivasi dalam melakukan kegiatannya tersebut.

Pendidikan menengah yang merupakan lanjutan pendidikan dasar terdiri atas pendidikan menengah umum dan pendidikan menengah kejuruan. Pendidikan menengah kejuruan merupakan pendidikan pada jenjang pendidikan menengah yang mengutamakan pengembangan kemampuan peserta didik untuk dapat bekerja dalam bidang tertentu, kemampuan beradaptasi di lingkungan kerja, melihat peluang kerja dan mengembangkan diri di kemudian hari. Pendidikan menengah kejuruan memiliki tujuan untuk meningkatkan kecerdasan, pengetahuan, kepribadian, akhlak mulia, serta keterampilan untuk hidup mandiri dan mengikuti pendidikan lebih lanjut sesuai dengan kejuruannya. Untuk dapat mewujudkan tujuan pendidikan nasional, kurikulum SMK disusun dengan memperhatikan tahapan perkembangan siswa dan kesesuaian dengan jenis pekerjaan, lingkungan sosial, kebutuhan pembangunan nasional, perkembangan ilmu pengetahuan dan teknologi, serta kesenian. Karena itu, penyusunannya bertumpu pada landasan filosofis, ekonomis, dan yuridis tertentu. 
Pendidikan formal merupakan salah satu kebutuhan pokok manusia. Anak-anak biasanya cenderung mempunyai minat untuk melanjutkan pendidikan yang lebih baik dari orang tuanya karena didorong oleh keinginan untuk berprestasi, mencapai cita-cita atau bahkan memperbaiki kualitas hidup di masa yang akan datang. Tetapi itu semua dipengaruhi oleh kondisi sosial dan kondisi ekonomi orang tuanya. Semakin tinggi pendidikan yang ditempuh semakin tinggi pula biaya yang dibutuhkan. Oleh karena itu orang tua harus mempunyai penghasilan guna membiayai bermacam-macam kebutuhan sekolah anak dan kebutuhan lainnya.

Orang tua dengan tingkat pendidikan yang lebih tinggi akan memberikan dorongan terhadap anaknya untuk memotivasi anaknya agar lebih giat lagi dalam belajar sebagai bekal untuk melanjutkan pendidikan pada jenjang yang lebih tinggi. Setiap orang tua berharap anaknya lebih baik dari orang tuanya terutama dalam hal pendidikan dengan harapan di masa yang akan datang kualitas hidup anaknya akan lebih baik dari kehidupan sekarang.Indikator kondisi sosial dan ekonomi keluarga/orang tua yang dapat digunakan sebagai parameter atau pengukuran tingkat kondisi sosial dan kondisi ekonomi orang tua dalam penelitian ini adalah: (1) pendidikan orang tua, (2) lingkungan, (3) pendapatan orang tua, dan (4) kepemilikan harta.

Faktor lain yang juga sangat berpengaruh adalah lingkungan tempat tinggal, baik lingkungan keluarga maupun lingkungan masyarakat. Kondisi lingkungan keluarga yang nyaman dan mendukung akan sangat berpengaruh terhadap minat anak dalam pendidikannya. Demikian juga halnya dengan keberadaan tingkat pendapatan keluarga yang mempunyai peranan penting terhadap proses perkembangan dan proses pendidikan anak. Dengan perekonomian keluarga yang cukup, siswa mendapat kesempatan untuk mengembangkan kecakapannya. Kondisi sosial ekonomi orang tua yang memadai serta pendidikan orang tua yang tinggi akan memperkuat minat siswa untuk melanjutkan pendidikannya sampai pada jenjang yang lebih tinggi. Dengan ditopang oleh kondisi sosial dan kondisi ekonomi orang tua yang lebih baik atau kuat, sangat dimungkinkan minat anak untuk melanjutkan sekolah dalam hal ini melanjutkan pendidikan ke SMK menjadi lebih kuat.

\section{Hipotesis Penelitian:}

Berdasarkan landasan teori agar penelitian dapat terarah, maka penulis mengajukan hipotesis penelitian sebagai berikut:

1. Ada pengaruh yang signifikan antara lingkungan siswa dengan minat siswa SMP di Kabupaten Bantul dalam melanjutkan sekolah ke SMK.

2. Ada pengaruh yang signifikan informasi pendidikan dengan minat siswa SMP di Kabupaten Bantul dalam melanjutkan sekolah ke SMK.

3. Ada pengaruh yang signifikan kesejahteraan keluarga dengan minat siswa SMP di Kabupaten Bantul dalam melanjutkan sekolah ke SMK.

4. Ada pengaruh yang signifikan pemenuhan keluarga dengan minat siswa SMP di Kabupaten Bantul dalam melanjutkan sekolah ke SMK.

5. Ada pengaruh bersama yang signifikan antara lingkungan pendidikan, informasi pendidikan, kesejahteraan keluarga, dan pemenuhan keluarga terhadap minat siswa SMP di Kabupaten Bantul dalam melanjutkan sekolah ke SMK.

\section{METODE}

Penelitian tentang Minat Siswa SMP Negeri Melanjutkan ke SMK ditinjau dari Latar Belakang Sosial Ekonomi Keluarga di Kabupaten Bantul menggunakan pendekatan bersifat ex post facto dimana keterikatan antar variabel bebas dengan variabel bebas, maupun antar variabel bebas dengan variabel terikat sudah terjadi secara alami (Sukardi, 2010: 165). Penelitian ini dilakukan dengan mengumpulkan fakta-fakta berdasarkan pengukuran terhadap gejala yang terjadi pada responden, tidak melakukan perlakuan-perlakuan maupun manipulasi-manipulasi terhadap variabel penelitiannya. Penelitian ex post facto adalah penemuan empiris yang dilakukan secara sistematis, peneliti tidak melakukan kontrol terhadap variabel-variabel bebas karena manifestasinya sudah terjadi atau variabel-variabel tersebut secara inheren tidak dapat dimanipulasi. Penelitian ex post facto menguji hipotesis tetapi tidak memberikan perlakuan-perlakuan tertentu karena 
sesuatu sebab kurang etis untuk memberikan perlakuan atau memberikan manipulasi. Biasanya karena alasan etika manusiawi, atau gejala atau peristiwa tersebut sudah terjadi dan ingin menelusuri faktor-faktor penyebabnya atau hal-hal yang mempengaruhinya.

Sebagai variabel terikat dalam penelitian ini adalah minat masuk SMK (Y), sedangkan variabel bebasnya adalah latar belakang sosial ekonomi keluarga yang meliputi: lingkungan siswa (X1), informasi pendidikan (X2), kesejahteraan keluarga (X3), dan pemenuhan keluarga (X4).

Populasi dalam penelitian ini adalah seluruh siswa kelas IX SMP Negeri yang berjumlah 48 sekolah di Kabupaten Bantul, dengan jumlah siswa sebanyak 7718 siswa. Pengambilan sampel menggunakan teknik proporsional random sampling, yaitu sampel yang dihitung berdasarkan perbandingan. Proporsional berarti dari setiap SMP yang terpilih, diambil sampel individu dengan memperhatikan proporsi siswa di masingmasing daerah populasi. Random sampling berarti pengambilan sampel individu mempunyai kesempatan yang sama untuk menjadi sampel penelitian. Siswa yang menjadi sampel penelitian diberikan angket untuk diisi. Sedangkan untuk menanggulangi adanya data yang hilang, kosong atau rusak (tidak lengkap) maka diberi tambahan $5 \%$. Penentuan jumlah sampel berdasarkan rumus untuk ukuran sampel dengan menggunakan model perhitungan Krejcie dan Morgan (1960:4).

Analisis yang dipergunakan untuk mengolah data penelitian ini meliputi analisis statistik deskriptif yang meliputi: distribusi frekuensi, nilai sentral, nilai sebaran dan proporsi. Analisis inferensial ini bertujuan untuk mengetahui pengaruh variabel-variabel yang akan diteliti.

Dalam penelitian ini unit analisis yang dipakai adalah siswa. Berdasarkan hal tersebut, maka penelitian ini menggunakan populasi siswa SMP Negeri di Kabupaten Bantul. Responden dan sumber datanya adalah siswa kelas IX. Dikarenakan jumlah siswa jumlahnya cukup besar maka penentuan responden dari siswa dilaksanakan dengan melakukan penarikan sampel siswa.

Pengumpulan data dalam penelitian ini menggunakan angket baik variabel terikat maupun variabel bebas. Angket atau kuesio- ner digunakan dalam penelitian ini karena dengan alat ini dapat diketahui tentang keadaan responden, pengetahuan, sikap, dan pendapatnya. Di samping itu ada beberapa pertimbangan yaitu: angket dapat dijawab menurut kecepatan masing-masing responden, dapat dibagikan serempak kepada banyak responden, lebih cepat, hanya responden yang tahu akan dirinya, dan kepada responden dapat diberikan pertanyaan yang sama.

Uji signifikansi untuk menentukan valid tidaknya sebuah butir instrumen dilakukan dengan membandingkan harga rxy, dengan harga kritik rtabel. Jika harga rxy hitung lebih besar dari harga $r$ tabel pada taraf signifikansi $5 \%$, maka butir instrumen dikatakan valid, artinya instrumen tersebut benarbenar mengukur faktor yang hendak diukur. Sebaliknya jika harga rxy hitung lebih kecil dan harga pada taraf signifikansi 5\%, maka butir instrumen dinyatakan gugur. Kriteria kelayakan menurut Sugiyono, (2011: 188) dengan $\mathrm{N}=32$ pada taraf signifikansi $5 \%$ adalah 0,349 . Sehingga butir yang mempunyai nilai lebih besar dari 0,349 dinyatakan valid dan jika butir memiliki nilai validitas kurang dari 0,349 maka butir tersebut dinyatakan tidak valid atau gugur.

Pengujian dilakukan dengan cara terlebih dahulu mencari butir yang valid dan tidak valid pada masing-masing instrumen. Uji reliabilitas dilakukan untuk mencari tingkat ketepatan, ketelitian atau keakuratan sebuah instrumen. Analisis yang dipakai untuk uji reliabilitas dalam penelitian ini adalah dengan rumus Alpha (Sugiyono, 2010: 365). Instrumen penelitian dengan variabel lingkungan siswa, informasi pendidikan, kesejahteraan keluarga, pemenuhan keluarga dan minat siswa dilihat pada tabel 8 dapat dikatakan reliabel karena nilai Alfa Cronbach's $>0,7$.

Dalam penelitian ini, untuk mendeskripsikan data setiap variabel dilakukan dengan perhitungan statistik deskriptif kuantitatif. Tabulasi data untuk masingmasing ubahan dilakukan terhadap skor yang telah diperoleh. Dengan menggunakan modul frequencies program SPSS 18, diperoleh Rerata (M), Median (Me), Modus (Mo) dan simpangan baku $(\mathrm{Sd})$, rentang nilai minimum dan maksimum setiap ubahan akan ditampilkan distribusi frekuensi dan histogram untuk masing-masing variabel.Pengujian hipotesis 
dalam penelitian ini digunakan analisis korelasi product moment dan analisis regresi linier ganda. Untuk menguji hipotesis perlu dihitung besarnya koefisien korelasi antara masing-masing variabel bebas dengan variabel terikat. Rumus yang digunakan untuk menghitung koefisien korelasi tersebut adalah rumus korelasi product moment. Teknik analisis data digunakan untuk membuktikan atau menguji hipotesis penelitian. Analisis data pada penelitian menggunakan analisis regresi linier berganda. Sebagai kriteria penerimaan dan penolakan digunakan tingkat signifikan $5 \%$ jika $\mathrm{p}<0,05$, maka Ho diterima.

\section{HASIL PENELITIAN DAN PEMBAHASAN}

Deskripsi data penelitian diperoleh rerata atau mean $(\mathrm{M})$, standar deviasi (SD), modus (Mo), median (Me), skor maksimum, skor minimum, varian, dan skewness disertai histogram untuk setiap variabel penelitian. Deskripsi data dapat dilihat sebagai berikut:

\begin{tabular}{lccccc}
\multicolumn{7}{c}{ Tabel 1.} & Statistik \\
\hline Mean & X1 & X2 & X3 & X4 & Y \\
Median & 72,60 & 38,17 & 31,81 & 38,63 & 71,71 \\
Mode & 73,00 & 38,00 & 31,00 & 38,00 & 72,00 \\
Std. Deviation & 78 & 36 & 32 & 31 & 78 \\
Variance & 10,179 & 6,969 & 7,311 & 9,244 & 9,220 \\
Skewness & 103,607 & 48,566 & 53,449 & 85,452 & 85,013 \\
Std. Error of Skewness & $-1,174$ & $-0,009$ & 0,306 & 0,189 & $-0,314$ \\
Minimum & 0,128 & 0,128 & 0,128 & 0,128 & 0,128 \\
Maximum & 50 & 24 & 20 & 18 & 46 \\
\hline
\end{tabular}

Data kuantitatif yang diperoleh dari keempat variabel independent akan diolah dengan cara membandingkan persentase perolehan skor setiap responden pada tiap kasus dengan kriteria penilaian.

Tabel 2. Data Persentase Lingkungan Siswa

\begin{tabular}{ccccc}
\hline Kategori & Kelas Interval & Jumlah & Persentase (\%) & $\begin{array}{c}\text { Presentase } \\
\text { Komulatif }\end{array}$ \\
\hline Sangat Tinggi & $\mathrm{X} \geqq 83$ & 68 & 18,68 & 18,68 \\
Tinggi & $83>\mathrm{X} \geq 73$ & 118 & 32,42 & 51,10 \\
Rendah & $73>\mathrm{X} \geq 62$ & 126 & 34,61 & 85,71 \\
Sangat Rendah & $\mathrm{X}<62$ & 52 & 14,29 & 100 \\
\hline \multicolumn{5}{r}{ Total } \\
\end{tabular}

Tabel 2 menunjukkan bahwa terdapat 18,68\% (68 siswa) berada pada kategori sangat tinggi, $32,42 \%$ (118 siswa) berada pada kategori tinggi, 34,61\% (126 siswa) berada pada kategori rendah; dan 14,29\% (52 siswa) berada pada kategori sangat rendah. Dengan demikian dapat disimpulkan bahwa data lingkungan siswa dengan kategori rendah sebesar 34,61\% (126 siswa). 
Tabel 3. Data Persentase Informasi Pendidikan

\begin{tabular}{llccc}
\hline Kategori & Kelas Interval & Jumlah & Persentase $(\%)$ & $\begin{array}{c}\text { Presentase } \\
\text { Komulatif }\end{array}$ \\
\hline Sangat Tinggi & $\mathrm{X} \geq 45$ & 78 & 21,43 & 21,43 \\
Tinggi & $45>\mathrm{X} \geq 38$ & 111 & 30,49 & 51,92 \\
Rendah & $38>\mathrm{X} \geq 31$ & 122 & 33,52 & 85,44 \\
Sangat Rendah & $\mathrm{X}<31$ & 53 & 14,56 & 100 \\
\hline \multicolumn{1}{c}{ Total } & & 364 & 100 & \\
\hline
\end{tabular}

Tabel 3 menunjukkan bahwa terdapat $21,43 \%$ (78 siswa) berada pada kategori sangat tinggi; $30,49 \%$ (111 siswa) berada pada kategori tinggi; 33,52\% (122 siswa) berada pada kategori rendah dan $14,56 \%$ (53 siswa) berada pada kategori sangat rendah. Dengan demikian dapat disimpulkan bahwa data informasi pendidikan dengan kategori rendah sebesar 33,52\% (122 siswa).

Tabel 4. Data Presentase Kesejahteraan Keluarga

\begin{tabular}{|c|c|c|c|c|}
\hline Kategori & Kelas Interval & Jumlah & Persentase $(\%)$ & $\begin{array}{l}\text { Presentase } \\
\text { Komulatif }\end{array}$ \\
\hline Sangat Tinggi & $X \geqq 39$ & 69 & 18,96 & 18,96 \\
\hline Tinggi & $39>X \geq 32$ & 111 & 30,49 & 49,45 \\
\hline Rendah & $32>X \geq 24$ & 126 & 34,62 & 84,07 \\
\hline Sangat Rendah & $X<24$ & 58 & 15,93 & 100 \\
\hline \multicolumn{2}{|c|}{ Total } & 364 & 100 & \\
\hline
\end{tabular}

Tabel 4 menunjukkan bahwa terdapat 18,96 \% (69 siswa) berada pada kategori sangat tinggi; $30,49 \%$ (111 siswa) berada pada kategori tinggi; 34,62 \% (126 siswa) berada pada kategori rendah; dan 15,93\% (58 siswa) berada pada kategori sangat rendah. Dengan demikian dapat disimpulkan bahwa data kesejahteraan keluargadengan kategori rendah sebesar $34,62 \%$ (126 siswa).

Tabel 5. Rangkuman Hasil Analisis Varians (ANAVA) Tahap Lanjut dengan Uji Scheffe

\begin{tabular}{ccccc}
\hline Kategori & Kelas Interval & Jumlah & Persentase (\%) & $\begin{array}{c}\text { Presentase } \\
\text { Komulatif }\end{array}$ \\
\hline Sangat Tinggi & $\mathrm{X} \geqq 48$ & 73 & 20,05 & 20,05 \\
Tinggi & $48>\mathrm{X} \geq 39$ & 97 & 26,65 & 46,70 \\
Rendah & $39>\mathrm{X} \geq 29$ & 144 & 39,56 & 86,26 \\
Sangat Rendah & $\mathrm{X}<29$ & 50 & 13,74 & 100 \\
\hline \multicolumn{5}{r}{ Total } \\
\end{tabular}


Tabel 5 menunjukkan bahwa terdapat 20,05 \% (73 siswa) berada pada kategori sangat tinggi, 26,65\% (97 siswa) berada pada kategori tinggi; 39,56\% (144 siswa) berada pada kategori rendah; dan 13,74\% (50 siswa) berada pada kategori sangat rendah. Dengan demikian dapat disimpulkan bahwa data pemenuhan keluarga dengan kategori rendah sebesar 39,56\% (144 siswa).

Tabel 6. Data Persentase Minat Siswa

\begin{tabular}{|c|c|c|c|c|}
\hline Kategori & Kelas Interval & Jumlah & Persentase $(\%)$ & $\begin{array}{l}\text { Presentase } \\
\text { Komulatif }\end{array}$ \\
\hline Sangat Tinggi & $X \geqq 81$ & 61 & 16,76 & 16,76 \\
\hline Tinggi & $81>X \geq 72$ & 141 & 38,74 & 55,5 \\
\hline Rendah & $72>X \geq 62$ & 121 & 33,24 & 88,74 \\
\hline Sangat Rendah & $X<62$ & 41 & 11,26 & 100 \\
\hline \multicolumn{2}{|c|}{ Total } & 364 & 100 & \\
\hline
\end{tabular}

Tabel 6 menunjukkan bahwa terdapat 16,76\% (61 siswa) berada pada kategori sangat tinggi; 38,74 \% (141 siswa) berada pada kategori tinggi; 33,24 \% (121 siswa) berada pada kategori rendah; dan 11,26\% (41 siswa) berada pada kategori sangat rendah.
Dengan demikian dapat disimpulkan bahwa data minat siswa dengan kategori rendah sebesar 38,74\% (141 siswa). berikut:

Uji prasyarat analisis adalah sebagai

Tabel 7. Hasil Uji Normalitas

\begin{tabular}{|c|c|c|c|c|c|c|}
\hline & & $\mathrm{X} 1$ & $\mathrm{X} 2$ & $\mathrm{X} 3$ & $\mathrm{X} 4$ & $\mathrm{Y}$ \\
\hline \multicolumn{2}{|l|}{$\mathrm{N}$} & 364 & 364 & 364 & 364 & 364 \\
\hline Normal & Mean & 72,60 & 38,17 & 31,81 & 38,63 & 71,71 \\
\hline Parameter $^{\mathrm{a}, \mathrm{b}}$ & Sdt. Deviation & 10,179 & 6,969 & 7,311 & 9,244 & 9,220 \\
\hline \multirow[t]{3}{*}{ Difference } & Absolute & 0,065 & 0,054 & 0,060 & 0,071 & 0,061 \\
\hline & Positive & 0,039 & 0,049 & 0,060 & 0,071 & 0,039 \\
\hline & Negative & $-0,065$ & $-0,054$ & $-0,053$ & $-0,050$ & $-0,061$ \\
\hline \multicolumn{2}{|c|}{ Kolmogorov - Smirnov Z } & 1,234 & 1,031 & 1,154 & 1,348 & 1,167 \\
\hline \multicolumn{2}{|c|}{ Asymp. Sig. (2-tailed) } & 0,095 & 0,239 & 0,139 & 0,053 & 0,131 \\
\hline
\end{tabular}

Berdasarkan tabel 7 dapat diketahui bahwa nilai Asymp. Sig. (2-tailed) untuk masing-masing variabel mempunyai nilai signifikansi lebih besar dari 0,05 maka data dinyatakan berdistribusi normal.

Tabel 8. Hasil Uji Linieritas

\begin{tabular}{ccccc}
\hline No & Variabel & F Deviation from Linearity & Sig. & Kesimpulan \\
\hline 1 & $\mathrm{X}_{1}-\mathrm{Y}$ & 2,142 & 0,05 & Linier \\
2 & $\mathrm{X}_{2}-\mathrm{Y}$ & 1,250 & 0,05 & Linier \\
3 & $\mathrm{X}_{3}-\mathrm{Y}$ & 1,250 & 0,05 & Linier \\
4 & $\mathrm{X}_{4}-\mathrm{Y}$ & 1,077 & 0,05 & Linier \\
\hline
\end{tabular}


Berdasarkan tabel 8 maka dapat disimpulkan bahwa nilai $\mathrm{F}$ pada masing-masing variabel lebih besar dari $0,05(\mathrm{~F}>0,05)$.
Sehingga dapat disimpulkan bahwa variabel independent mempunyai hubungan yang linier terhadap variabel dependent.

Tabel 9. Hasil Uji Heteroskedastisitas

\begin{tabular}{|c|c|c|c|c|c|c|}
\hline Model & \multicolumn{2}{|c|}{ Sum of Squares } & $M e$ & Mean Square & $F$ & Sig. \\
\hline Regression & \multicolumn{2}{|c|}{77,072} & 4 & 19,268 & \multirow[t]{2}{*}{0,770} & \multirow[t]{2}{*}{0,546} \\
\hline Residual & \multicolumn{2}{|c|}{8987,274} & 359 & 25,034 & & \\
\hline Total & \multicolumn{2}{|c|}{9064,346} & 363 & & & \\
\hline \multicolumn{7}{|c|}{ a. Predictors: (Constant), $X_{4}, X_{3}, X_{2}, X_{1}$} \\
\hline \multirow{2}{*}{\multicolumn{2}{|c|}{ Variabel }} & \multicolumn{2}{|c|}{$\begin{array}{c}\text { Unstandardized } \\
\text { Coefficients }\end{array}$} & $\begin{array}{c}\text { Standardized } \\
\text { Coefficients }\end{array}$ & \multirow[t]{2}{*}{$t$} & \multirow[t]{2}{*}{ Sig. } \\
\hline & & $B$ & Std. Error & Beta & & \\
\hline \multicolumn{2}{|c|}{ (Constant) } & 0,234 & 3,139 & & 0,075 & 0,941 \\
\hline \multicolumn{2}{|c|}{ Lingkungan Siswa } & 0,041 & 0,027 & 0,084 & 1,561 & 0,119 \\
\hline \multicolumn{2}{|c|}{ Informasi Pendidikan } & 0,004 & 0,038 & 0,005 & 0,098 & 0,922 \\
\hline \multicolumn{2}{|c|}{ Kesejahteraan Keluarga } & 0,032 & 0,037 & 0,046 & 0,854 & 0,394 \\
\hline \multicolumn{2}{|c|}{ Pemenuhan Keluarga } & 0,014 & 0,29 & 0,025 & 0,471 & 0,638 \\
\hline
\end{tabular}

b. Dependent Variable: $Y$

Berdasarkan tabel 9 dapat diketahui bahwa nilai signifikansi uji $F$ dan uji $t$ antara variabel independent $X_{1}, X_{2}, X_{3}$, dan $X_{4}$ lebih besar dari 0,05 (sig. $\mathrm{F}>0,05$ dan sig. $\mathrm{t}>$ 0,05 ), dengan demikian model regresi ini tidak terjadi heteroskedastisitas.

Tabel 10. Hasil Uji Multikolinieritas

\begin{tabular}{ccc}
\hline variabel & \multicolumn{2}{c}{ Collinearity Statistics } \\
\cline { 2 - 3 } & Tollerance & VIF \\
\hline X1 & 0,944 & 1,060 \\
X2 & 0,972 & 1,029 \\
X3 & 0,933 & 1,072 \\
X4 & 0,959 & 1,043 \\
\hline
\end{tabular}

Berdasarkan hasil uji multikolinieritas pada tabel 24, dapat dilihat bahwa besamya nilai VIF untuk variabel independent bernilai kurang dari 10 (VIF < 10), dan mempunyai toleransi lebih besar dari 0,1 (tolerance $>0,1$ ).
Maka dapat disimpulkan bahwa variabel independent tidak terjadi multikolinearitas. Sehingga didapat bahwa proses analisis regresi linier berganda dapat dilanjutkan. 
Tabel 11. Hasil Uji Regresi Linier Berganda

\begin{tabular}{cccccc}
\hline \multirow{2}{*}{ Variabel } & \multicolumn{2}{c}{$\begin{array}{c}\text { Unstandardized } \\
\text { Coefficients }\end{array}$} & $\begin{array}{c}\text { Standardized } \\
\text { Coefficients }\end{array}$ & \multirow{2}{*}{$t$} & Sig. \\
\cline { 2 - 4 } & $B$ & Std. Error & Beta & & \\
\hline (Constant) & 44,623 & 4,430 & & 10,074 & 0,000 \\
Lingkungan Siswa (X1) & 0,533 & 0,037 & 0,588 & 14,225 & 0,000 \\
Informasi Pendidikan (X2) & $-0,113$ & 0,054 & 0,085 & $-2,092$ & 0,037 \\
Kesejahteraan Keluarga (X3) & $-0,122$ & 0,052 & 0,092 & $-2,324$ & 0,021 \\
Pemenuhan Keluarga (X4) & $-0,089$ & 0,041 & 0,089 & $-2,170$ & 0,031 \\
\hline
\end{tabular}

a. Dependent Variable: Minat Siswa (Y)

Berdasarkan hasil analisis regresi linier berganda, maka dapat dibuat garis persamaan regresi sebagai berikut :

$$
\begin{aligned}
Y & =44,623+0,533 X_{1}-0,113 X_{2}-0,122 X_{3} \\
& -0,089 X_{4}
\end{aligned}
$$

Tabel 12. Hasil uji hipotesis simultan (Uji F) variabel lingkungan siswa, informasi pendidikan, kesejahteraan keluarga, dan pemenuhan keluarga dengan minat siswa.

\begin{tabular}{cccccc}
\hline Model & Sum of Squares & $d f$ & Mean Square & $F$ & Sig. \\
Regression & 12966,234 & 4 & 3241,559 & 65,037 & $0,000^{\mathrm{a}}$ \\
Residual & 17893,313 & 359 & 49,842 & & \\
\hline Total & 30859,547 & 363 & & & \\
\hline
\end{tabular}

Berdasarkan tabel 12 dapat diketahui bahwa nilai $p$-value $<5 \%$, maka dapat disimpulkan bahwa lingkungan siswa, informasi pendidikan, kesejahteraan keluarga, dan pemenuhan keluarga berpengaruh terhadap minat siswa.

Tabel 13. Hasil Uji T

\begin{tabular}{lccc}
\hline No. & Hubungan & $\mathrm{t}$ & Sig. 2 tailed \\
\hline 1 & $\mathrm{X} 1-\mathrm{Y}$ & 2,028 & 0,043 \\
2 & $\mathrm{X} 2-\mathrm{Y}$ & $-51,088$ & 0,000 \\
3 & $\mathrm{X} 3-\mathrm{Y}$ & $-58,538$ & 0,000 \\
4 & $\mathrm{X} 4-\mathrm{Y}$ & $-44,959$ & 0,000 \\
\hline
\end{tabular}

Berdasarkan tabel 13 dapat diketahui bahwa nilai sig $<5 \%$ untuk semua variabel 
Tabel 14. Hasil Uji Koefisien Determinasi $\left(\mathrm{R}^{2}\right)$ Variabel lingkungan siswa, informasi pendidikan, kesejahteraan keluarga, dan pemenuhan keluarga terhadap minat siswa.

\begin{tabular}{ccccc}
\hline Model & $R$ & $R$ Square & $\begin{array}{c}\text { Adjusted } R \\
\text { Square }\end{array}$ & $\begin{array}{c}\text { Std. Error of the } \\
\text { Estimate }\end{array}$ \\
\hline 1 & $0,648^{\mathrm{a}}$ & 0,420 & 0,414 & 7,060 \\
\hline
\end{tabular}

Nilai $R$ Square yang ditunjukkan pada tabel 27 sebesar 0,420 menerangkan bahwa variabel lingkungan siswa, informasi pendidikan, kesejahteraan keluarga, dan pemenuhan keluarga mampu menjelaskan tentang variabel independent yang memberikan sumbangan efektif sebesar $42 \%$ terhadap variabel minat siswa. Sedangkan $58 \%$ minat siswa dipengaruhi oleh faktor-faktor selain keempat variabel tersebut.

Berdasarkan uji hipotesis ditemukan bahwa seluruh variabel independent memiliki pengaruh terhadap minat siswa. Hal ini menunjukkan bahwa untuk meningkatkan minat siswa, sekolah ataupun orang tua diharapkam berperan penting dalam meningkatkan informasi pendidikan, lingkungan belajar yang kondusif, dan kesejahteraan keluarga bagi anak, dalam menempuh pendidikan.

Lingkungan sosial atau lingkungan belajar sangat mempengaruhi minat belajar siswa. Lingkungan memberikan stimulasi kepada siswa untuk berkonsentrasi, menumbuhkan motivasi ataupun menumbuhkan sikap dan daya bersaing dengan teman-teman sebayanya. Seperti diketahui bahwa kondisi belajar mengajar yang efektif adalah adanya minat dan perhatian siswa dalam belajar. Minat belajar siswa sangat bergantung pada lingkungan belajar. Lingkungan belajar dalam konteks pendidikan mempunyai peranan penting yang besar dan strategis. Hal ini disebabkan karena lingkungan adalah tempat interaksi langsung dalam belajar. Lingkungan yang menumbukan daya saing (kompetitif) bagi akan menumbuhkan minat belajar untuk mendapatkan performa yang terbaik. Dengan adanya daya saing dari lingkungan, anak akan terpicu untuk belajar lebih giat. Khususnya untuk minat siswa melanjutkan sekolah ke SMK.

Informasi pendidikan merupakan seperangkat komponen yang saling berhubungan dan saling bekerjasama untuk mencapai beberapa tujuan. Sebuah sistem terdiri dari bagian-bagian saling berkaitan yang beroperasi bersama untuk mencapai beberapa sasaran, berarti sebuah sistem bukanlah seperangkat unsur yang tersusun secara tak teratur, tetapi terdiri dari unsur yang dapat dikenal sebagai bagian yang saling melengkapi karena mempunyai sasaran dan tujuan yang sama.

Informasi adalah data yang telah diolah menjadi sebuah bentuk yang berarti bagi penerimanya dan bermanfaat dalam pengambilan keputusan saat ini atau saat mendatang. Menurut UU No. 20 tahun 2003 adalah usaha sadar dan terencana untuk mewujudkan suasana belajar dan proses pembelajaran agar peserta didik secara aktif mengembangkan potensi dirinya untuk memiliki kekuatan spiritual keagamaan, pengendalian diri, kepribadian, kecerdasan, akhlak mulia, serta keterampilan yang diperlukan dirinya, masyarakat, bangsa, dan negara. Sedangkan pendidikian pada dasarnya adalah proses komunikasi yang di dalamnya mengandung transformasi pengetahuan, nilai-nilai dan keterampilan-keterampilan di dalam dan di luar sekolah yang berlangsung sepanjang hayat, dan generasi ke generasi. Untuk itu informasi pendidikan harus didisain untuk mendukung dalam mendukung menjalankan program pendidikan yang akan dilakukan, khususnya untuk menjaring siswa yang siap bekerja. Sehingga maksud dilaksanakannya manajemen sistem informasi pendidikan dapat benar benar sesuai tujuan.

Kesejahteraan keluarga, hal ini berkaitan dengan status ekonomi orang tua atau tingkat pendapatan yang diperoleh orang tua. Dalam rangka mempertahankan hidup dan mengembangkan kehidupannya, manusia harus dapat memenuhi kebutuhan hidupnya baik kebutuhan, primer, sekunder, maupun tersier, agar dapat hidup layak sesuai dengan harkat dan martabatnya sebagai anggota masyarakat. Dalam usaha memenuhi ke- 
butuhan yang tak terbatas sementara alatalat pemuas kebutuhan yang jumlahnya sangat terbatas maka manusia cenderung memenuhi kebutuhannya menurut skala ke-pentingan (skala prioritas) dan kemampuan untuk memenuhinya, kemampuan di sini erat kaitannya dalam masalah pembiayaan dan pembiayaan itu sendiri diperoleh dari pendapatan atau penghasilan.

Pengaruh orang tua, khususnya orang tua yang memiliki latar belakang sebagai orang tidak mampu dapat memberikan minat yang positif bagi anaknya untuk melanjutkan sekolah ke SMK. Orang tua yang memiliki latar belakang ekonomi menengah ke bawah, akan mendukung atau menyekolahkan anaknya ke SMK dengan harapan besok setelah sekolah bisa langsung kerja. Orang tua yang memiliki latar belakang ekonomi menengah ke bawah akan memberikan nasehat agar anaknya meneruskan sekolah ke SMK, melihat ekonomi yang masih minim atau kurang. Karena setiap orang tua ingin setelah mendapatkan pendidikan jenjang SMK, anaknya bisa langsung kerja sesuai back ground siswa. Seperti orang tua yang latar belakangnya adalah seorang petani, buruh, atau pedagang sedikit lebih banyak menginginkan anaknya langsung bekerja. Beda halnya dengan orang tua yang orang tuanya berwirausaha dengan suskses, guru, pegawai kantoran atau PNS, cenderung orang tua mengarahkan dan membimbing anaknya untuk meneruskan sekolah hingga sarjana. Peranan orang tua memiliki pengaruh yang positif terhadap minat siswa karena dengan adanya rasa patuh dan hormat terhadap orang tua, dapat mempermudah orang tua menjadikan anak tidak malas bekerja dan siap memikirkan hari esok, dimana kemandirian dan mencari pekerjaan dikemudian hari sangatlah sulit, untuk itu pendidikan yang tinggi dapat menunjang kehidupannya kelak. Dengan peranan orang tua, di rumah anak belajar memahami hidup dengan melihat situasi ekonomi yang kurang, tanggung jawab, kemandirian, moral, spiritual, dan meniru aktifitas yang dilakukan orang tua yang baik. Kondisi finansial orang tua secara tidak sadar dapat menjadi sarana belajar bagi anak. Hal tersebut dilakukan untuk memiliki sikap siap dalam berusaha mencari pekerjaan di diri anak, maka kebanyakan orang tua kalau anak segera kerja, maka anak akan disekolahkan ke SMK.

Berdasarkan penelitian yang dilakukan, dapat disimpulkan bahwa terdapat pengaruh antara status sosial ekonomi dengan minat siswa SMP untuk melanjutkan ke SMK dengan nilai $\mathrm{F}$ sebesar $65,037>\mathrm{F}$ tabel $(2,37)$ yang dapat disimpulkan bahwa peran keempat variabel tersebut signifikan. Sehingga apabila semakin tinggi status sosial ekonomi orang tua murid SMP maka minat untuk melanjutkan ke SMK rendah. Sebagai implikasi dari penelitian ini bahwa perlu adanya kesungguhan dari berbagai pihak untuk merealisasikan minat siswa SMP yang ingin meneruskan pendidikannya ke SMK. Karena, pemerintah telah memprogramkan untuk menambahkan jumlah sekolah kejuruan di Indonesia.

\section{SIMPULAN}

Berdasarkan hasil dan pembahasan penelitian yang dikemukakan di atas maka kesimpulan yang dapat dikemukakan dalam penelitian ini adalah sebagai berikut:

1. Terdapat pengaruh yang signifikan antara lingkungan siswa dengan minat siswa SMP di Kabupaten Bantul dalam melanjutkan sekolah ke SMK yang dibuktikan dengan $t_{\text {hitung }}$ sebesar 2,028 lebih besar dari $t_{\text {tabel }}$ sebesar 1,978 ( $t_{\text {hitung }} 2,028$ $\left.>t_{\text {tabel }} 1,978\right)$ dan nilai $r=0,627$ yang mempunyai makna nilai pengaruh tersebut moderate dan paling dominan mempengaruhi minat siswa ke SMK. Sehingga hipotesis pertama diterima.

2. Terdapat pengaruh yang signifikan antara informasi pendidikan dengan minat siswa SMP di Kabupaten Bantul dalam melanjutkan sekolah ke SMK yang dibuktikan dengan $t_{\text {hitung }}$ sebesar $-51,088$ lebih besar dari $t_{\text {tabel }}$ sebesar $1,978 \quad\left(t_{\text {hitung- }}\right.$ $\left.51,088>t_{\text {tabel }} 1,978\right)$ dan nilai $r=-0,181$ yang mempunyai makna nilai pengaruh tersebut lemah. Sehingga hipotesis kedua diterima.

3. Terdapat pengaruh yang signifikan antara kesejahteraan keluarga dengan minat siswa SMP di Kabupaten Bantul dalam melanjutkan sekolah ke SMK yang dibuktikan dengan $t_{\text {hitung }}$ sebesar -58,538 lebih besar dari $\mathrm{t}_{\text {tabel }}$ sebesar 1,978 ( $_{\text {hitung }}{ }^{-}$ $\left.58,538>t_{\text {tabel }} 1,978\right)$ dan nilai $r=-0,227$ 
yang mempunyai makna nilai pengaruh tersebut lemah. Sehingga hipotesis ketiga diterima.

4. Terdapat pengaruh yang signifikan antara pemenuhan keluarga dengan minat siswa SMP di Kabupaten Bantul dalam melanjutkan sekolah ke SMK yang dibuktikan dengan $t_{\text {hitung }}$ sebesar $-44,959$ lebih besar dari $\mathrm{t}_{\text {tabel }}$ sebesar 1,978 $\left(\mathrm{t}_{\text {hitung }}{ }^{-}\right.$ $\left.44,959>t_{\text {tabel }} 1,978\right)$ dan nilai $r=-0,156$ yang mempunyai makna nilai pengaruh tersebut lemah. Sehingga hipotesis keempat diterima.

5. Terdapat pengaruh yang signifikan antara lingkungan siswa, informasi pendidikan, kesejahteraan keluarga, dan pemenuhan keluarga dengan minat siswa SMP di Kabupaten Bantul dalam melanjutkan sekolah ke SMK yang dibuktikan dengan dengan $\mathrm{R}=0,648 ; \mathrm{R}^{2}=0,420 ;$ Adjusted $R$ Square 0,414 dan $\mathrm{F}_{\text {hitung }}$ sebesar 65,037 lebih besar dari $F_{\text {tabel }}$ sebesar 2,37 $\left(\mathrm{F}_{\text {hitung }} 65,037>\mathrm{F}_{\text {tabel }}\right)$. Sehingga variabel lingkungan siswa, informasi pendidikan, kesejahteraan keluarga, dan pemenuhan keluarga mampu menjelaskan tentang variabel independent yang memberikan sumbangan efektif sebesar $42 \%$ terhadap variabel minat siswa. Sedangkan 58\% minat siswa dipengaruhi oleh faktorfaktor selain keempat variabel tersebut.

\section{DAFTAR PUSTAKA}

Dalyono. (2010). Psikologi Pendidikan. Jakarta : Rineka Cipta

Depdiknas. (2003). Undang - Undang RI No. 20, tentang Standar Nasional Pendidikan. Jakarta.
Depdiknas, Data Pokok SMK Direktorat Pembinaan Sekolah Menengah Kejuruan Departemen Pendidikan Nasional. (2009).

Diambil pada tanggal 30 Agustus 2009 dari : http://datapokok.dtpsmk.net/index.php? $\underline{n a m a}=$ prop $=04 \& \mathrm{kab}=0402 \&$ dstatus $=\&$ $\underline{\mathrm{kk}}$

Depdiknas. (2010). Peraturan Pemerintah RI No. 17, tentang Pengelolaan dan Penyelenggaraan Pendidikan. Jakarta.

Gerungan. 2004. Psikologi Sosial. Bandung: PT. Refika Aditama.

Krejcie and Morgan.(1960). Educational and Psychological Measurement. Texas :The NEA Research Bulletin.

Pem.Kab.Bantul, Peta Kemiskinan Absolut dan Persentase di Kabupaten Bantul.

Diambil pada tanggal 28 Agustus 2009 dari : http://www.bantulkab.go.id/datagakin/index.php.

Sugiyono (2011). Metode Penelitian Pendidikan Pendekatan Kuantitatif, Kualitatif, dan $R$ \& D. Bandung : Alfabeta

Sugiyono. (2010). Statistika untuk Penelitian. Bandung : Alfabeta

Sukardi. (2011). Statistika Pendidikan untuk Penelitian dan Pengelolaan Diklat. Yogyakarta : Usaha Keluarga

Sukardi. (2010). Metode Penelitian Pendidikan Kompetensi dan Prakteknya. Jakarta : Bumi Aksara.

Wingkel, W.S. (1985). Psikologi Pendidikan dan Evaluasi Belajar. Jakarta: Gramedia. 